\title{
Effect of terbutaline on hyperpnoea-induced bronchoconstriction and urinary club cell protein 16 in athletes
}

\author{
A. J. Simpson, ${ }^{\mathbf{1}}$ E. Tufvesson, ${ }^{\mathbf{2}}$ S. D. Anderson, ${ }^{3}$ L. M. Romer, ${ }^{\mathbf{1}}$ L. Bjermer, ${ }^{\mathbf{2}}$ and P. Kippelen ${ }^{\mathbf{1}}$ \\ ${ }^{1}$ Centre for Sports Medicine and Human Performance, Brunel University, Uxbridge, United Kingdom; ${ }^{2}$ Department of \\ Respiratory Medicine \& Allergology, Lund University, Lund, Sweden; and ${ }^{3}$ Department of Respiratory and Sleep Medicine, \\ Royal Prince Alfred Hospital, Camperdown, New South Wales, Australia
}

Submitted 20 June 2013; accepted in final form 4 September 2013

\begin{abstract}
Simpson AJ, Tufvesson E, Anderson SD, Romer LM, Bjermer L, Kippelen P. Effect of terbutaline on hyperpnoeainduced bronchoconstriction and urinary club cell protein 16 in athletes. J Appl Physiol 115: 1450-1456, 2013. First published September 12, 2013; doi:10.1152/japplphysiol.00716.2013.-Repeated injury of the airway epithelium caused by hyperpnoea of poorly conditioned air has been proposed as a key factor in the pathogenesis of exercise-induced bronchoconstriction (EIB) in athletes. In animals, the short-acting $\beta_{2}$-agonist terbutaline has been shown to reduce dry airflow-induced bronchoconstriction and the associated shedding of airway epithelial cells. Our aim was to test the efficacy of inhaled terbutaline in attenuating hyperpnoea-induced bronchoconstriction and airway epithelial injury in athletes. Twentyseven athletes with EIB participated in a randomized, double-blind, placebo-controlled, crossover study. Athletes completed an 8-min eucapnic voluntary hyperpnoea $(\mathrm{EVH})$ test with dry air on two separate days $15 \mathrm{~min}$ after inhaling $0.5 \mathrm{mg}$ terbutaline or a matching placebo. Forced expiratory volume in $1 \mathrm{~s}\left(\mathrm{FEV}_{1}\right)$ and urinary concentration of the club cell (Clara cell) protein 16 (CC16, a marker of airway epithelial perturbation) were measured before and up to $60 \mathrm{~min}$ after EVH. The maximum fall in $\mathrm{FEV}_{1}$ of $17 \pm 8 \%$ (SD) on placebo was reduced to $8 \pm 5 \%$ following terbutaline $(P<0.001)$. Terbutaline gave bronchoprotection (i.e., post-EVH FEV 1 fall $<10 \%)$ to $22(81 \%)$ athletes. EVH caused an increase in urinary excretion of CC16 in both conditions $(P<0.001)$, and terbutaline significantly reduced this rise (pre- to postchallenge CC16 increase $416 \pm 495 \mathrm{pg} / \mu \mathrm{mol}$ creatinine after placebo vs. $315 \pm 523 \mathrm{pg} / \mu \mathrm{mol}$ creatinine after terbutaline, $P=$ 0.016). These results suggest that the inhalation of a single therapeutic dose of terbutaline offers significant protection against hyperpnoeainduced bronchoconstriction and attenuates acute airway epithelial perturbation in athletes.
\end{abstract}

exercise-induced bronchoconstriction; epithelial injury; inhaled $\beta_{2^{-}}$ agonist; Clara cell

EXERCISE-INDUCED BRONCHOCONSTRICTION (EIB) is defined as a transient narrowing of the airways that occurs during or shortly after strenuous exercise. The main stimulus for EIB is evaporative water and heat loss from the airway surface as a consequence of heating and humidifying large volumes of unconditioned air (2). Whereas EIB can be found in both the general population and in athletes, the latter are more at risk for EIB (11), and they often develop EIB later in life (16). We have previously proposed that, in athletes, EIB is a consequence of repeated injury and repair of the airway epithelium in response to long hours of conditioning air during strenuous training (3).

Address for reprint requests and other correspondence: P. Kippelen, Centre for Sports Medicine \& Human Performance, Brunel Univ., Heinz Wolff Bldg., Uxbridge, Middlesex, UB8 3PH, UK (e-mail: pascale.kippelen@brunel.ac.uk).
During exercise, as ventilation increases, the conditioning of inspired air extends progressively toward the peripheral airways. If the replacement of water to the airway surface is insufficient, dehydration injury of the distal airways may occur (3). In addition, mechanical stress associated with high airflow and/or bronchoconstriction may accelerate disruption of the epithelial cell layer (24). Following epithelial injury, bulk plasma may leak from the microcirculation to repair the damage to the epithelial cells (35). The process of plasma exudation could then expose the airway smooth muscle to substances that alter its growth and affect its contractile properties, leading to the development of airway hyperresponsiveness and EIB in susceptible individuals (3). In support of this idea, increased levels of bronchial epithelial cells have been found in induced sputum of asthmatic patients with EIB (18), as well as in various athletic populations [elite swimmers (8) and recreational runners (12)]. Increases in tenascin expression and inflammatory cell counts in the lung biopsies of elite crosscountry skiers (23) and of elite swimmers (7) have also provided direct evidence of exercise-induced airway remodeling (a sign of repeated injury-repair) and inflammation.

Using the concentration of the lung-specific club cell (Clara cell) protein (CC16) in extrapulmonary fluids, our group previously established that dry air hyperpnoea causes an acute perturbation of the airway epithelium (6). Consistent with our finding, serum and urinary CC16 concentration have also be shown to increase following bouts of cycling (9), running (12, 29), and swimming (10, 17, 37). In swimming, however, because of the noxious effect of trichloramines on club cell function (10), exposure to chlorination by-products may act as a confounder (27). In our recent study on running (5), we showed that inhalation of warm humid air attenuated the rise in urinary CC16 postexercise (likely as a result of a reduced water loss from the airway surface). We are now aiming to establish whether pharmacological agents also have the potency to blunt, or even to completely abolish, the $\mathrm{CC} 16$ response associated with exercise hyperpnoea.

In a healthy human epithelium, airway surface liquid is mainly regulated via apical $\mathrm{Cl}^{-}$secretion and $\mathrm{Na}^{+}$absorption [passive flow of water occurring along the osmotic gradient (21)]. Pharmacological interventions can modify ion transport. In vitro, the $\beta_{2}$-agonist terbutaline has been shown to increase the transport of $\mathrm{Cl}^{-}$toward the airway lumen (14). Moreover, in canine peripheral airways challenged with dry air, infusion of terbutaline attenuated airway narrowing and reduced epithelial cell shedding (40). To date, the impact of pharmacological agents administered directly to the airways has not been tested. We reasoned that, if terbutaline facilitates replacement of water at the airway surface level during exposure to dry air, pretreat- 
ment with inhaled terbutaline may attenuate hyperpnoea-induced airway injury in humans.

In this study, we tested the efficacy of a single dose of inhaled terbutaline at reducing hyperpnoea-induced airway epithelial perturbation in athletes. We also aimed to confirm the bronchoprotective effect of terbutaline in athletes with EIB. Our hypothesis was that $0.5 \mathrm{mg}$ terbutaline will attenuate the increase in urinary concentration of $\mathrm{CC} 16$ and the fall in forced expiratory volume in $1 \mathrm{~s}\left(\mathrm{FEV}_{1}\right)$ following $8 \mathrm{~min}$ of eucapnic voluntary hyperpnoea $(\mathrm{EVH})$ with dry air in athletes.

\section{METHODS}

Subjects. The study population consisted of 27 athletes with EIB. EIB was confirmed by a fall of $\geq 10 \%$ in $\mathrm{FEV}_{1}$ following an 8-min EVH challenge during a screening visit. Participants were nonsmokers, free from respiratory infections for $4 \mathrm{wk}$ before the study, and with no known chronic medical condition other than asthma or EIB. Regular swimmers ( $>1 \mathrm{~h} / \mathrm{wk})$ were excluded. Participants abstained from alcohol, caffeine, and exercise on the day of testing, and medication was withheld as follows: short-acting $\beta_{2}$-agonist (SABA) treatments were withheld for a minimum of $8 \mathrm{~h}$, long-acting $\beta_{2^{-}}$ agonist (LABA) treatments for $24 \mathrm{~h}$, inhaled corticosteroid (ICS) treatments for $12 \mathrm{~h}$, and combination therapies of LABA + ICS for 24 $\mathrm{h}$ (28). Written informed consent was obtained from all participants after the study protocol, and potential risks were explained. The study was approved by the United Kingdom National Health Service Research Ethics Committee (NHS REC reference no.: 10/H0716/30).

Experimental design. The study used a randomized, double-blind, placebo-controlled, crossover experimental design. All participants attended two experimental visits, separated by at least 2 days but no more than $3 \mathrm{wk}$, during which they were administered either $0.5 \mathrm{mg}$ of terbutaline or a placebo $15 \mathrm{~min}$ before completion of an EVH challenge. The primary end points were changes in urinary CC16 concentration and $\mathrm{FEV}_{1}$.

Experimental visits were conducted in the morning between 8:00 and 11:00 A.M. [to standardize for fluctuations in CC16 levels throughout the day (4)] and started with the recording of baseline lung function. The active drug (i.e., $0.5 \mathrm{mg}$ of terbutaline) was administered via a dry powder inhaler (Bricanyl Turbohaler; Astra Zeneca, London, UK). An empty demonstration Turbohaler was used for administration of the placebo. Subjects were instructed to take one deep, hard inhalation of the drug or placebo and to hold their breath for $10 \mathrm{~s}$. Posttreatment lung function manoeuvers were repeated at 10 min. The EVH challenge started 15 min after treatment. Spontaneous recovery of $\mathrm{FEV}_{1}$ to baseline levels following the EVH challenge was measured at 2, 5, 10, 15, 20, 30, and $60 \mathrm{~min}$.

Subjects ingested $200 \mathrm{ml}$ of water $1 \mathrm{~h}$ before each visit. They ingested a further $400 \mathrm{ml}$ upon arrival at the laboratory and then 200 $\mathrm{ml}$ at 30-min intervals. Two baseline urine samples were obtained: the first, on arrival at the laboratory, which was discarded; the second, 30-60 min later and immediately before administration of the drug, which was used as baseline. Further urine samples were collected 30 and 60 min after the EVH challenge. All samples were stored, without preservatives, at $-80^{\circ} \mathrm{C}$. Atopic status was tested by skin prick testing during the first experimental visit, with the procedure starting $40 \mathrm{~min}$ post-EVH.

CC16 analysis. To avoid prostatic contamination, the first $100 \mathrm{ml}$ of urine were systematically discarded in male participants (4). CC16 was measured using the Human Clara Cell Protein ELISA kit from BioVendor (Modrice, Czech Republic) according to the manufacturer's instructions. The detection limit for CC16 was $20 \mathrm{pg} / \mathrm{ml}$. All urine samples were analyzed for creatinine using a COBAS 6000 analyzer (Roche Diagnostics, Bromma, Sweden). CC16 results were expressed as picograms of excreted mediator per micromole of creatinine.
Lung function measurements. Forced expiratory manoeuvers were conducted using a spirometer (MicroLoop, Micromedical, Kent, UK) in accordance with ERS/ATS guidelines (28). Manoeuvers were repeated in triplicate at baseline and in duplicate postchallenge. The equations of Quanjer et al. (36) were used for calculation of predicted values. At all pre- and post-EVH time points, the best $\mathrm{FEV}_{1}$ and forced vital capacity (FVC) values of two reproducible manoeuvers were kept for analysis. The maximum fall in $\mathrm{FEV}_{1}$ and FVC was expressed as a percentage from the posttreatment value. The trapezoidal method was used to calculate the area under the $\mathrm{FEV}_{1}$ time curve $\left(\mathrm{FEV}_{1}-\mathrm{AUC}_{0-60}\right)$ and was calculated from the posttreatment $\mathrm{FEV}_{1}$ value. The degree of bronchoprotection afforded by terbutaline was calculated by subtracting the maximum fall in $\mathrm{FEV}_{1}$ on the drug treatment day from the maximum fall in $\mathrm{FEV}_{1}$ on the placebo day, and expressing it as a percentage of the placebo. The largest peak expiratory flow (PEF) value from the three (baseline) or two (post-EVH) reproducible manoeuvers was recorded at each time point. Mean forced expiratory flow between 25 and $75 \%$ of the FVC $\left(\mathrm{FEF}_{25-75}\right)$ and instantaneous forced expiratory flows at 25, 50, and $75 \%$ of FVC $\left(\mathrm{FEF}_{75}, \mathrm{FEF}_{50}\right.$, and $\mathrm{FEF}_{25}$, respectively) were taken from the manoeuvers with the largest sum of $\mathrm{FEV}_{1}$ and FVC.

EVH challenge. An 8-min EVH challenge was performed on a Eucapsys system (SMTEC, Nyon, Switzerland), with dry gases drawn from medical gas cylinders. Briefly, participants breathed a gas mixture containing $5 \% \mathrm{CO}_{2}, 20 \% \mathrm{O}_{2}$, and balance $\mathrm{N}_{2}$ at a target ventilation of $85 \%$ predicted maximum voluntary ventilation (MVV), calculated as 30 times baseline $\mathrm{FEV}_{1}$ (1). The ventilation achieved during the first visit was used as the target ventilation for the second visit.

Atopic status. A skin prick test was carried out using standardized allergen extracts of house dust mite, timothy grass, and cat hair (ALK-Abello, Reading, UK). Saline and histamine were used as negative and positive controls, respectively. A test was defined positive if the reaction wheel was $\geq 3 \mathrm{~mm}$.

Data analysis. Sample size requirement was dictated by our previous work (5). With 21 participants we were previously able to detect a between-condition effect in urinary $\mathrm{CC} 16$ excretion following bronchial provocation challenge. All data were checked for normality using the Shapiro-Wilk test. CC16 data were not normally distributed; therefore, natural logarithmic transformation was applied. Differences between conditions for $\mathrm{FEV}_{1}$ (in 1) and $\mathrm{CC} 16$ were analyzed using paired-sample $t$-test. $\mathrm{FEV}_{1}$ maximum fall post-EVH (in \%) and $\mathrm{FEV}_{1}-\mathrm{AUC}_{0-60}$ were nonnormally distributed and therefore analyzed using a Wilcoxon signed-rank test. Differences between conditions and times were analyzed using a repeated-measures ANOVA. In cases of statistical significance, least-significance difference pairwise comparisons were conducted post hoc. Data were analyzed using SPSS 18.0 for Windows (SPSS, Chicago, IL), and significance was assessed at the 0.05 level. Results are expressed as means $\pm \mathrm{SD}$, unless otherwise stated.

\section{RESULTS}

Participant characteristics. Twenty seven participants (11 females) completed the study. Mean age, height, and body mass were $27 \pm 9 \mathrm{yr}, 174 \pm 8 \mathrm{~cm}$, and $74 \pm 13 \mathrm{~kg}$, respectively. Participants were involved in summer sports (athletics, cycling, football, rugby, or rowing) and trained for $8 \pm 3 \mathrm{~h} / \mathrm{wk}$ in aerobic activities. Twenty three participants competed at a local level and three competed at the national or international level. Participants had $9 \pm 6 \mathrm{yr}$ of experience in their sport. Participants' medical diagnosis, current treatment, and atopic status are presented in Table 1. One participant had an underlying diagnosis of Crohn's disease. However, at the time of the study, he was asymptomatic and was not treated for this condition. During the screening visit, baseline $F_{E V}$ was 
Table 1. Participant characteristics

\begin{tabular}{|c|c|c|c|c|c|c|c|c|c|c|}
\hline \multicolumn{2}{|r|}{ Gender } & Atopic Status & $\begin{array}{c}\text { Baseline } \mathrm{FEV}_{1}, \\
\text { \%pred }\end{array}$ & Previous Diagnosis & Treatment & $\begin{array}{l}\text { Prescribed ICS } \\
\text { Dose, } \mu \mathrm{g} / \text { day }\end{array}$ & \multicolumn{3}{|c|}{ Post-EVH Maximum FEV 1 Fall, \% } & Protection, $\%$ \\
\hline 1 & M & + & 95 & Asthma + EIB & Combination, SABA & 1,600 & 17 & 18 & 15 & 17 \\
\hline 3 & M & + & 99 & Asthma + EIB & Combination & 400 & 16 & 12 & 18 & 0 \\
\hline 4 & $\mathrm{~F}$ & + & 108 & EIB & SABA, ICS & 200 & 21 & 13 & 12 & 8 \\
\hline 5 & M & + & 97 & & & & 16 & 15 & 4 & 73 \\
\hline 6 & $\mathrm{~F}$ & + & 92 & Asthma & SABA, ICS & 200 & 10 & 14 & 8 & 43 \\
\hline 9 & $\mathrm{~F}$ & + & 93 & Asthma & Combination & 400 & 10 & 13 & 2 & 85 \\
\hline 10 & M & + & 99 & Asthma & SABA, ICS & 600 & 36 & 26 & 25 & 4 \\
\hline 11 & M & - & 99 & & & & 11 & 11 & 6 & 45 \\
\hline 12 & M & + & 85 & Asthma & & & 9 & 14 & 6 & 57 \\
\hline 13 & $\mathrm{~F}$ & + & 103 & Asthma & & & 27 & 29 & 9 & 69 \\
\hline 14 & M & + & 109 & EIB & SABA & & 14 & 11 & 7 & 36 \\
\hline 15 & $\mathrm{~F}$ & - & 99 & Asthma + EIB & Combination & 400 & 19 & 16 & 7 & 56 \\
\hline 20 & $\mathrm{~F}$ & - & 96 & Asthma & SABA & & 12 & 10 & 8 & 20 \\
\hline 21 & M & + & 94 & Asthma & SABA & & 15 & 13 & 7 & 46 \\
\hline 22 & $\mathrm{M}$ & + & 111 & Asthma & SABA, ICS & 200 & 16 & 16 & 1 & 94 \\
\hline 23 & $\mathrm{~F}$ & + & 102 & EIB & SABA, ICS & 200 & 23 & 28 & 6 & 79 \\
\hline 24 & F & + & 86 & Asthma & SABA & & 28 & 22 & 8 & 64 \\
\hline 25 & $\mathrm{~F}$ & - & 88 & EIB & & & 10 & 11 & 1 & 91 \\
\hline 26 & $\mathrm{~F}$ & + & 82 & Asthma + EIB & SABA & & 46 & 47 & 6 & 87 \\
\hline 27 & M & + & 91 & Asthma & SABA & & 16 & 11 & 2 & 81 \\
\hline \multicolumn{2}{|c|}{ Mean \pm SD } & & $97 \pm 8$ & & & & $19 \pm 10$ & $17 \pm 8$ & $8 \pm 5^{* * * *}$ & $54 \pm 28$ \\
\hline
\end{tabular}

M, male; F, female; Atopic status: +, positive skin prick response to house dust mite, timothy grass, and/or cat hair; FEV $\%_{1}$ pred, baseline forced expiratory volume in $1 \mathrm{~s}$ expressed relative to the predicted value (36); EIB, exercise-induced bronchoconstriction; SABA, short-acting $\beta_{2}$-agonist; LABA, long-acting


eucapnic voluntary hyperpnoea; protection, $\%$ bronchoprotection afforded by terbutaline. $* * *$ Significantly different from placebo $(P<0.001)$.

$>80 \%$ predicted in all participants, and the fall in $\mathrm{FEV}_{1}$ post-EVH averaged $19 \pm 10 \%$ (Table 1).

Baseline lung function and ventilation level during EVH. There was no difference between experimental visits in baseline lung function parameters (Table 2). Terbutaline had a small $\left(5 \pm 3 \%\right.$ increase in $\left.\mathrm{FEV}_{1}\right)$ but statistically significant bronchodilator effect $\left(P<0.001\right.$, Table 2). $\mathrm{FEF}_{25-75}, \mathrm{FEF}_{25}$,
$\mathrm{FEF}_{50}, \mathrm{FEF}_{75}$, and PEF also significantly increased postadministration of terbutaline $(P<0.001)$, whereas FVC remained unchanged (Table 2). No significant change in lung function was observed following administration of the placebo (Table 2). Minute ventilation was slightly but significantly larger in the terbutaline condition compared with the placebo condition: $102 \pm 20$ vs. $101 \pm 201(P=0.047)$. Participants reached

Table 2. Lung function results

\begin{tabular}{|c|c|c|c|c|c|}
\hline Lung Function Measurement & Pre-Rx & Post-Rx & Post-EVH, min value & $\begin{array}{l}\text { Pre-Rx vs. Post-Rx } \\
\quad(P \text { Value })\end{array}$ & $\begin{array}{l}\text { Post-Rx vs. Post-EVH } \\
\quad(P \text { Value })\end{array}$ \\
\hline \multicolumn{6}{|l|}{ Placebo } \\
\hline $\mathrm{FEV}_{1}, 1$ & $3.68 \pm 0.65$ & $3.67 \pm 0.67$ & $3.06 \pm 0.68$ & 0.316 & $<0.001$ \\
\hline $\mathrm{FEF}_{25-75}, 1 / \mathrm{s}$ & $3.27 \pm 0.90$ & $3.27 \pm 0.90$ & $2.17 \pm 0.69$ & 0.741 & $<0.001$ \\
\hline $\mathrm{FEF}_{25}, 1 / \mathrm{s}$ & $6.18 \pm 1.23$ & $6.12 \pm 1.23$ & $4.39 \pm 1.30$ & 0.495 & $<0.001$ \\
\hline $\mathrm{FEF}_{50}, 1 / \mathrm{s}$ & $3.57 \pm 0.86$ & $3.71 \pm 0.98$ & $2.47 \pm 0.78$ & 0.478 & $<0.001$ \\
\hline \multicolumn{6}{|l|}{ Terbutaline } \\
\hline $\mathrm{FEV}_{1}, 1$ & $3.65 \pm 0.64$ & $3.82 \pm 0.68$ & $3.43 \pm 0.63$ & $<0.001$ & $<0.001$ \\
\hline $\mathrm{FVC}, 1$ & $4.74 \pm 0.94$ & $4.73 \pm 0.95$ & $4.62 \pm 0.95$ & 0.796 & $<0.001$ \\
\hline $\mathrm{FEF}_{25-75}, 1 / \mathrm{s}$ & $3.26 \pm 0.93$ & $3.37 \pm 0.97$ & $3.07 \pm 0.86$ & $<0.001$ & $<0.001$ \\
\hline $\mathrm{FEF}_{25}, 1 / \mathrm{s}$ & $6.15 \pm 1.32$ & $6.78 \pm 1.41$ & $5.57 \pm 1.32$ & $<0.001$ & $<0.001$ \\
\hline $\mathrm{FEF}_{50}, 1 / \mathrm{s}$ & $3.77 \pm 1.06$ & $4.22 \pm 1.33$ & $3.45 \pm 0.84$ & $<0.001$ & $<0.001$ \\
\hline $\mathrm{FEF}_{75}, 1 / \mathrm{s}$ & $1.62 \pm 0.61$ & $2.16 \pm 1.43$ & $1.47 \pm 0.50$ & $<0.001$ & $<0.001$ \\
\hline
\end{tabular}

Pre-Rx, pretreatment with either $0.5 \mathrm{mg}$ terbutaline or placebo; Post-Rx, posttreatment; Post-EVH, min value, lowest value recorded after 8 min of eucapnic voluntary hyperpnoea of dry air; $\mathrm{FEV}_{1}$, forced expiratory volume in $1 \mathrm{~s} ; \mathrm{FVC}$, forced vital capacity; $\mathrm{FEF}_{25-75}$, mean forced expiratory flow between 25 and $75 \%$ of $\mathrm{FVC} ; \mathrm{FEF}_{X}$, forced expiratory flow at $\mathrm{X} \%$ of $\mathrm{FVC}$; PEF, peak expiratory flow. 
$80 \pm 8 \%$ MVV during the terbutaline visit and $78 \pm 7 \% \mathrm{MVV}$ during the placebo visit $(P=0.022)$.

Airway response to EVH. Terbutaline significantly inhibited the airway response to EVH. The maximum fall in $\mathrm{FEV}_{1}$ was reduced from $17 \pm 8 \%$ in the placebo condition to $8 \pm 5 \%$ in the terbutaline condition $(P<0.001$, Table 1$)$. $\mathrm{FEV}_{1}-\mathrm{AUC}_{0-60}$ was significantly reduced following terbutaline administration: from $425 \pm 283$ to $163 \pm 146 \% \min (P<0.001$, Fig. 1$)$. The bronchoprotection offered by terbutaline for the maximum percent fall in $\mathrm{FEV}_{1}$ and $\mathrm{FEV}_{1} \mathrm{AUC}_{0-60}$ was $54 \pm 28 \%$ (range $0-94 \%$, Table 1) and $60 \pm 30 \%$ (range $0-100 \%$ ), respectively. Terbutaline provided complete protection (i.e., post-EVH maximum \%fall in $\mathrm{FEV}_{1}<10 \%$ ) to 22 of the 27 participants $(81 \%)$.

EVH caused a significant decrease in FVC and in all expiratory flow values in both conditions $(P<0.001$, Table 2$)$. The decrease in FVC post-EVH was significantly attenuated with the administration of terbutaline (from $0.28 \pm 0.19$ to $0.12 \pm$ $0.111, P<0.001)$.

Urinary CC16. Three participants were excluded from the urinary CC16 statistical analysis, since their CC16 concentrations were below the detection point. In addition, one participant was excluded on the grounds of being an outlier. His CC16 measurements were highly variable at baseline $(2,457$ and $1,055 \mathrm{pg} / \mu \mathrm{mol}$ creatinine in the placebo and terbutaline condition, respectively), and he was the only participant to display a reduction in urinary $\mathrm{CC} 16$ excretion postchallenge in both the placebo and terbutaline condition $(-1,582$ and -261 $\mathrm{pg} / \mu \mathrm{mol}$ creatinine, respectively). The total number of data analyzed for CC16 was therefore 23.

Baseline urinary CC16 was not significantly different between conditions: $266 \pm 329$ in the placebo condition vs. $267 \pm 292 \mathrm{pg} / \mu \mathrm{mol}$ creatinine in the terbutaline condition $(P=0.695)$. EVH caused a significant increase in urinary excretion of $\mathrm{CC} 16$ in both conditions $(P<0.001)$, but the peak urinary release of CC16 postchallenge was significantly attenuated by terbutaline: from $682 \pm 788$ to $582 \pm 741 \mathrm{pg} / \mu \mathrm{mol}$ creatinine $(P=0.032)$. The magnitude of the change in urinary CC16 (pre- to maximum postchallenge CC16) was also significantly reduced after premedication with terbutaline (from $416 \pm$ 495 to $315 \pm 523 \mathrm{pg} / \mu$ mol creatinine, $P=0.016$; Fig. 2).

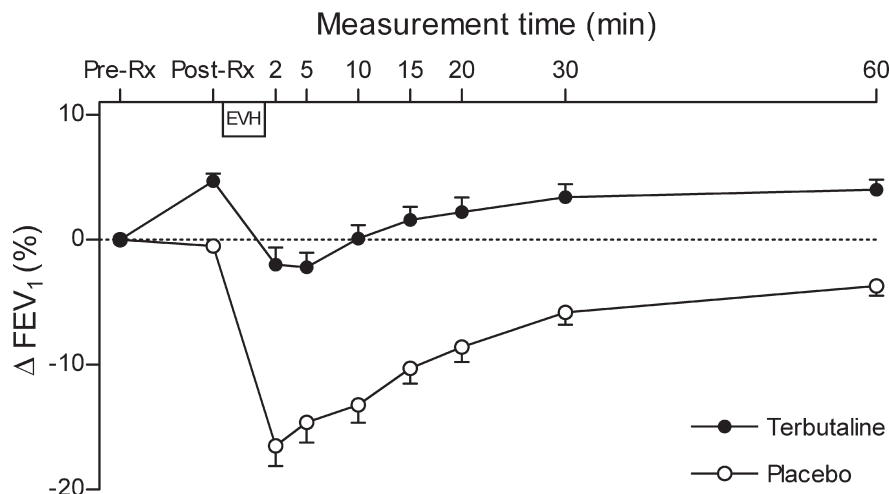

Fig. 1. Mean \pm SE percentage changes from baseline (Pre-Rx) in forced expiratory volume in $1 \mathrm{~s}\left(\mathrm{FEV}_{1}\right)$ after inhalation (Post-Rx) of $0.5 \mathrm{mg}$ terbutaline $(\bullet)$ or placebo $(O)$, and up to $60 \mathrm{~min}$ after eucapnic voluntary hyperpnoea $(\mathrm{EVH})$ of dry air in athletes with exercise-induced bronchoconstriction. Post$\mathrm{EVH}$ the area under the $\mathrm{FEV}_{1}$ time curve (measured from post-Rx) was significantly reduced following administration of terbutaline $(P<0.001)$.

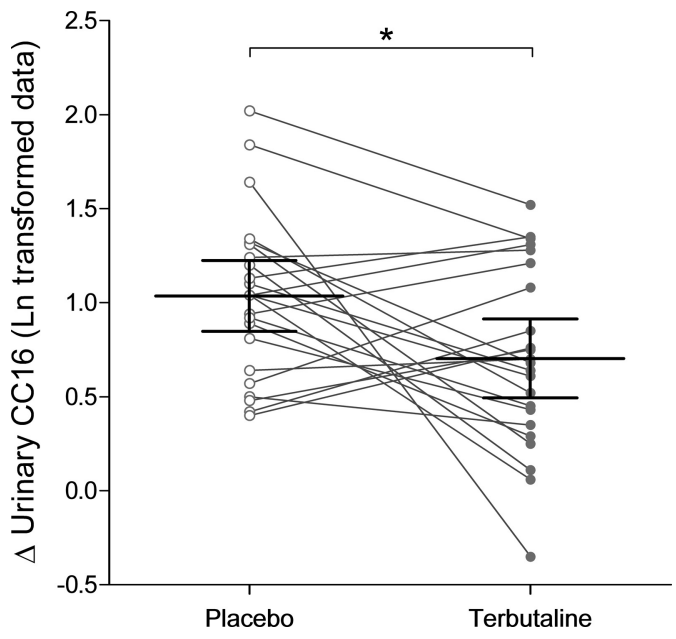

Fig. 2. Maximum change in urinary excretion of CC16 following EVH of dry air after pretreatment with placebo or $0.5 \mathrm{mg}$ of terbutaline in athletes with exercise-induced bronchoconstriction. Individual values with means $(95 \%$ confidence intervals). $* P<0.05$.

Repeated-measures ANOVA revealed significant time $(P<$ $0.001)$ and interaction $(P=0.002)$ effects, which indicate that terbutaline altered the kinetics of urinary $\mathrm{CC} 16$ excretion. Post hoc analysis revealed that urinary CC16 increased significantly from baseline to 30 and 60 min post-EVH in both conditions $(P<0.01)$. However, in the placebo condition, urinary CC16 continued to increase between 30 and 60 min of recovery $(P=$ 0.033 ), whereas it started to plateau at $30 \mathrm{~min}$ of recovery in the terbutaline condition. As a result, urinary concentrations of CC16 were significantly lower in the terbutaline condition at 60 min recovery compared with placebo $(P=0.007$, Fig. 3$)$.

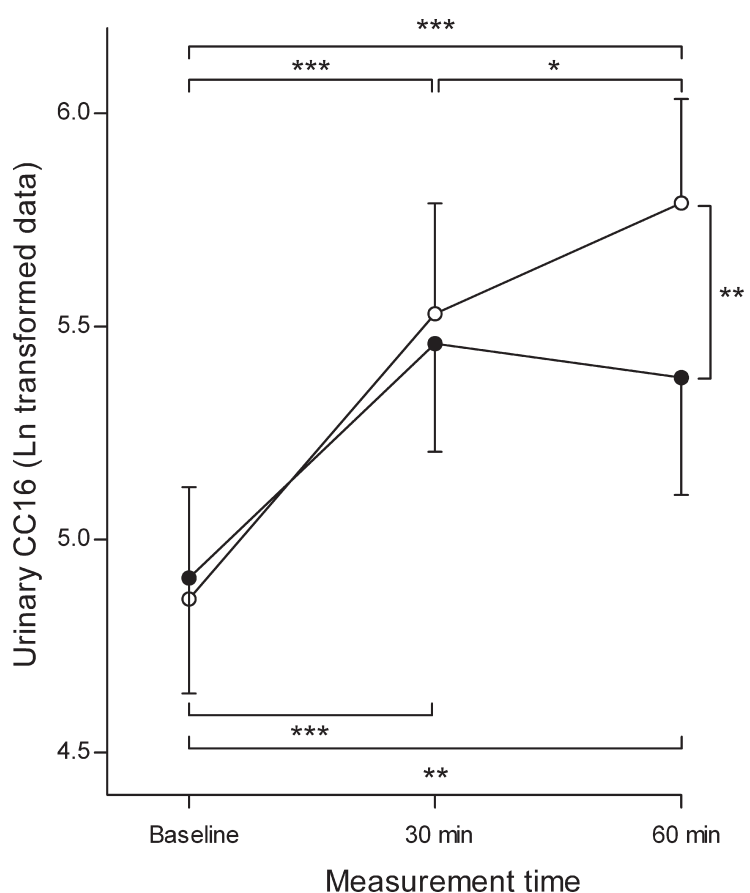

Fig. 3. Mean \pm SE urinary CC16 concentrations at baseline and 30 and $60 \mathrm{~min}$ post-EVH of dry air following pretreatment with $0.5 \mathrm{mg}$ terbutaline $(\bullet)$ or placebo $(\bigcirc)$ in athletes with exercise-induced bronchoconstriction. $* P<0.05$, $* * P<0.01$, and $* * * P<0.001$ 


\section{DISCUSSION}

The aim of this study was to test the efficacy of inhaled terbutaline at reducing hyperpnoea-induced airway epithelial injury and bronchoconstriction in athletes. We showed that a single therapeutic dose of terbutaline of $0.5 \mathrm{mg}$ was able to blunt the rise in urinary $\mathrm{CC} 16$ concentration following hyperpnoea of dry air. Moreover, we confirmed that terbutaline provided a significant degree of bronchoprotection to the majority $(81 \%)$ of the athletes. These results demonstrate the potential for inhaled $\beta_{2}$-agonists to attenuate, not only bronchoconstriction, but also acute airway epithelial perturbation in athletes with EIB.

This study supports our previous findings that hyperpnoea of dry air causes perturbation to the airway epithelium in athletes (6). It is also consistent with work conducted by our group (5) and others $(9,10,37)$ that showed that exercise hyperpnoea is associated with an increase in serum and urinary concentration of CC16 in athletes. The ability of parenteral $\beta_{2}$-agonists to reduce dry air-induced epithelial injury was previously demonstrated in animals $(33,40)$. We have now extended these findings by demonstrating that terbutaline can attenuate airway epithelial perturbation when administered by inhalation in the human lungs.

Airway epithelial perturbation in this study was assessed through changes in urinary CC16 concentration. CC16 is a protein secreted from the club cells located primarily in the distal airways (38). Acute increases in the concentration of CC16 in extrapulmonary fluids have previously been proposed to reflect a transient loss of the lung epithelial barrier integrity (20). An increase in urinary CC16 may also represent an increase in CC16 production/secretion by club cells in an attempt to modulate local inflammatory reactions (22). We have previously shown that hyperpnoea of dry air is associated with mast cell activation and inflammatory mediator release in athletes (26). Therefore, the rise in urinary CC16 following $\mathrm{EVH}$ in the current study may be the result of a combination of increased leakage of CC16 across the airway epithelium and increased production and/or secretion of the protein at the club cell level.

The use of a noninvasive marker (with multiple sampling time points) enabled us to test, for the first time, the efficacy of a pharmacological agent at attenuating hyperpnoea-induced airway perturbation in athletes. We showed that the rise in urinary $\mathrm{CC} 16$ concentration following a short period of hyperpnoea of dry air was significantly blunted with premedication with terbutaline. In vitro, terbutaline has been shown to increase the flow of $\mathrm{Cl}^{-}$toward the airway lumen (14), an action likely to be mediated through binding of the drug with $\beta_{2^{-}}$ receptors on epithelial cells and subsequent release of cAMP (39). Our research team previously demonstrated that reduction of the dehydration stress to the airways through inhalation of warm humid air limits epithelial cell perturbation after exercise (5). Similarly, in the current study, we propose that the reduction in urinary CC16 excretion post-EVH was the result of reduced dehydration of the airway epithelium mediated through terbutaline-enhanced water secretion.

An alternative interpretation of the results is that terbutaline did not affect the severity of epithelial perturbation per se but rather enhanced the speed of epithelial cell repair. Perkins et al. (34) showed in vitro that salbutamol stimulated both wound repair and spreading and proliferation of human lung epithelial cells. The potential of $\beta_{2}$-agonists to stimulate epithelial cell repair may explain why, in our study, urinary CC16 continued to increase between 30 and 60 min of recovery in the placebo condition, whereas it started to plateau in the terbutaline condition. We propose that terbutaline was able to stimulate the repair of the epithelial cells before the later time point (at $60 \mathrm{~min}$ ), and therefore reduced leakage of CC16 across the airway epithelial barrier.

A third contributing factor to our results could be the effect of terbutaline on the bronchial vascular system. In a murine model, terbutaline given in the instillate (intratracheally) reduced microvascular permeability during high-volume ventilation (15). $\beta_{2}$-agonists are thought to mediate vascular permeability, either directly [by relaxing the endothelial contractile proteins and thereby reducing gaps between endothelial cells (41)] or indirectly [by inhibiting vasoactive mediator release from the lung mast cells (13)]. We therefore cannot exclude that terbutaline, by reducing vascular leakage, limited the passage of CC16 in the bloodstream post-EVH.

Terbutaline in the present study was delivered through a dry powder inhaler (Turbuhaler). When delivered via Turbuhaler, terbutaline is known to reach all levels of the tracheobronchial tree, including the small airways (30). In our study, we noticed a significant increase in all forced expiratory flow parameters (including $\mathrm{FEF}_{50}$ and $\mathrm{FEF}_{75}$ ) postadministration of terbutaline. This is relevant in that the recruitment of the smaller airways in the conditioning of inspired air has been highlighted as the main mechanism for exercise-induced airway epithelial injury (3). Terbutaline has the potential to enhance osmotic-driven water flux to the airway lumen (14). Enhancement of water secretion to the larger airways may have therefore reduced the necessity for the smaller airways to be recruited in the conditioning process and may have protected those smaller airways against epithelial injury. The dispersion of terbutaline within the airways is known to be dependent on the inspiratory flow achieved with the Turbuhaler (31). Because inspiratory flow was not controlled in our study, interindividual differences in dispersion of the medication may account for the variation in the effectiveness of the terbutaline in attenuating the rise in CC16 post-EVH.

Although there was little difference in ventilation rates achieved by the athletes between the terbutaline and the placebo conditions, bronchoconstriction was more severe after placebo inhalation. Therefore, in our control condition, significant compressive stress may have occurred within the airways (32), which may have further compromised the integrity of the airway epithelial barrier. However, we did not find any significant correlation between the changes in urinary excretion of $\mathrm{CC} 16$ and the fall in $\mathrm{FEV}_{1}$ post-EVH under our two experimental conditions (data not shown). Similarly, in some of our previous work $(5,6)$, there was no difference in magnitude of urinary $\mathrm{CC} 16$ increase following exercise or EVH challenge tests in individuals with and without EIB. This therefore suggests that mild-to-moderate bronchoconstriction per se is unlikely to affect the extent of perturbation to the airway epithelium.

This paper is relevant to endurance athletes who are thought to repeatedly damage their airways through dehydration stress (3). Endurance (aerobic) athletes have an increased prevalence of EIB compared with their counterparts who perform anaer- 
obic exercise and with the general population (11). Repeated airway epithelial injury-repair has been highlighted as a key factor contributing to the increased prevalence of airway hyperresponsiveness in elite endurance athletes (3). Strategies aiming at preventing hyperpnoea-induced epithelial perturbation may therefore be beneficial in the prevention of EIB (25). Here, we showed that terbutaline acutely reduces airway epithelial perturbation. Chronic use of inhaled $\beta_{2}$-agonist may, however, cause tachyphylaxis and failure to respond to emergency bronchodilator treatment (19). Therefore, alternative treatments that act via similar pathways to $\beta_{2}$-agonists should be explored to devise appropriate long-term prevention strategies for airway injury in athletes.

In conclusion, this study demonstrates for the first time that premedication with a single, inhaled dose of terbutaline reduces hyperpnoea-induced airway epithelial perturbation in athletes. The evidence presented also provides further support to the use of terbutaline for prevention of EIB in athletes. We propose that terbutaline reduces epithelial perturbation mainly by enhancing water movement toward the airway lumen and by stimulating repair of the damaged airway epithelial cells. Because of the potential side effects of chronic use of inhaled $\beta_{2}$-agonists, we recommend that further research into the prevention of airway injury in athletes is conducted, targeting drugs that either enhance ion transport or stimulate epithelial cell repair.

\section{ACKNOWLEDGMENTS}

We thank Dr. Aldona Greenwood for help with the data collection.

\section{GRANTS}

The study was funded by the World Anti Doping Agency.

\section{DISCLOSURES}

No conflicts of interest, financial or otherwise, are declared by the authors.

\section{AUTHOR CONTRIBUTIONS}

Author contributions: A.J.S., E.T., and P.K. performed experiments; A.J.S., E.T., and P.K. analyzed data; A.J.S. and P.K. interpreted results of experiments; A.J.S. prepared figures; A.J.S. drafted manuscript; A.J.S., E.T., S.D.A., L.M.R., L.B., and P.K. approved final version of manuscript; E.T., S.D.A., L.M.R., L.B., and P.K. edited and revised manuscript; S.D.A. and P.K. conception and design of research.

\section{REFERENCES}

1. Anderson SD, Argyros GJ, Magnussen H, Holzer K. Provocation by eucapnic voluntary hyperpnoea to identify exercise induced bronchoconstriction. Br J Sports Med 35: 344-347, 2001.

2. Anderson SD, Daviskas E. The mechanism of exercise-induced asthma is. . . . J Allergy Clin Immunol 106: 453-459, 2000.

3. Anderson SD, Kippelen P. Exercise-induced bronchoconstriction: pathogenesis. Curr Allergy Asthma Rep 5: 116-122, 2005.

4. Andersson L, Lundberg P, Barregard L. Methodological aspects on measurement of clara cell protein in urine as a biomarker for airway toxicity, compared with serum levels. $J$ Appl Toxicol 27: 60-66, 2007.

5. Bolger C, Tufvesson E, Anderson SD, Devereux G, Ayres J, Bjermer L, Sue-Chu M, Kippelen P. Effect of inspired air conditions on exerciseinduced bronchoconstriction and urinary CC16 levels in athletes. J Appl Physiol 111: 1059-1065, 2011.

6. Bolger C, Tufvesson E, Sue-Chu M, Devereux G, Ayres JG, Bjermer L, Kippelen P. Hyperpnea-induced bronchoconstriction and urinary CC16 levels in athletes. Med Sci Sports Exerc 43: 1207-1213, 2011.

7. Bougault V, Loubaki L, Joubert P, Turmel J, Couture C, Laviolette M, Chakir J, Boulet LP. Airway remodeling and inflammation in competitive swimmers training in indoor chlorinated swimming pools. $J$ Allergy Clin Immunol 129: 351-358, 2012.
8. Bougault V, Turmel J, St-Laurent J, Bertrand M, Boulet L. Asthma, airway inflammation and epithelial damage in swimmers and cold-air athletes. Eur Respir J 33: 740-746, 2009.

9. Broeckaert F, Arsalane K, Hermans C, Bergamaschi E, Brustolin A, Mutti A, Bernard A. Serum clara cell protein: a sensitive biomarker of increased lung epithelium permeability caused by ambient ozone. Environ Health Perspect 108: 533-537, 2000.

10. Carbonnelle S, Francaux M, Doyle I, Dumont X, Burbure C, Morel G, Michel O, Bernard A. Changes in serum pneumoproteins caused by short-term exposures to nitrogen trichloride in indoor chlorinated swimming pools. Biomarkers 7: 464-476, 2002.

11. Carlsen KH, Anderson SD, Bjermer L, Bonini S, Brusasco V, Canonica W, Cummiskey J, Delgado L, Del Giacco SR, Drobnic F. Exercise-induced asthma, respiratory and allergic disorders in elite athletes: epidemiology, mechanisms and diagnosis: part I of the report from the joint task force of the european respiratory society (ERS) and the european academy of allergy and clinical immunology (EAACI) in cooperation with GA2LEN. Allergy 63: 387-403, 2008.

12. Chimenti L, Morici G, Paterno A, Santagata R, Bonanno A, Profita M, Riccobono L, Bellia V, Bonsignore MR. Bronchial epithelial damage after a half-marathon in nonasthmatic amateur runners. Am J Physio Lung Cell Mol Physiol 298: L857-L862, 2010.

13. Church MK, Hiroi J. Inhibition of IgE-dependent histamine release from human dispersed lung mast cells by anti-allergic drugs and salbutamol. $\mathrm{Br}$ J Pharmacol 90: 421-429, 1987.

14. Davis B, Marin MG, Yee JE, Nadel JA. Effect of terbutaline on movement of $\mathrm{Cl}^{-}$and $\mathrm{Na}^{+}$across trachea of the dog in vitro. Am Rev Respir Dis 120: 547-552, 1979.

15. de Prost N, Dreyfuss D, Ricard J, Saumon G. Terbutaline lessens protein fluxes across the alveolo-capillary barrier during high-volume ventilation. Intensive Care Med 34: 763-770, 2008.

16. Fitch K. Beta(2)-agonists at the olympic games. Clin Rev Allergy Immunol 31: 259-268, 2006.

17. Font-Ribera L, Kogevinas M, Zock J, Gómez FP, Barreiro E, Nieuwenhuijsen MJ, Fernandez P, Lourencetti C, Pérez-Olabarría M, Bustamante M, Marcos R, Grimalt JO, Villanueva CM. Short-term changes in respiratory biomarkers after swimming in a chlorinated pool. Environ Health Perspect 118: 1538-1544, 2010.

18. Hallstrand TS, Moody MW, Aitken ML, Henderson WR Jr. Airway immunopathology of asthma with exercise-induced bronchoconstriction. $J$ Allergy Clin Immunol 116: 586-593, 2005.

19. Hancox R, Subbarao P, Kamada D, Watson R, Hargreave F, Inman M. B-2-agonist tolerance and exercise-induced bronchospasm. Am J Respir Crit Care Med 165: 1068-1070, 2002.

20. Hermans C, Bernard A. Lung epithelium-specific proteins: characteristics and potential applications as markers. Am J Respir Crit Care Med 159: 646-678, 1999.

21. Hollenhorst MI, Richter K, Fronius M. Ion transport by pulmonary epithelia (Abstract). J Biomed Biotechnol 2011: 174306, 2011.

22. Jorens PG, Sibille Y, Goulding NJ, Van Overveld FJ, Herman AG, Bossaert L, De Backer WA, Lauwerys R, Flower RJ, Bernard A. Potential role of Clara cell protein, an endogenous phospholipase A2 inhibitor, in acute lung injury. Eur Respir J 8: 1647-1653, 1995.

23. Karjalainen EM, Laitinen A, Sue-Chu M, Altraja A, Bjermer L, Laitinen LA. Evidence of airway inflammation and remodeling in ski athletes with and without bronchial hyperresponsiveness to methacholine. Am J Respir Crit Care Med 161: 2086-2091, 2000.

24. Kippelen P, Anderson SD. Airway injury during high-level exercise. $\mathrm{Br}$ J Sports Med 46: 385-390, 2012.

25. Kippelen P, Fitch KD, Anderson SD, Bougault V, Boulet LP, Rundell KW, Sue-Chu M, McKenzie DC. Respiratory health of elite athletes preventing airway injury: a critical review. Br J Sports Med 46: 471-476, 2012.

26. Kippelen P, Larsson J, Anderson SD, Brannan JD, Dahlén B, Dahlén SE. Effect of sodium cromoglycate on mast cell mediators during hyperpnea in athletes. Med Sci Sports Exerc 42: 1853-1860, 2010.

27. Lagerkvist BJ, Bernard A, Blomberg A, Bergstrom E, Forsberg B, Holmstrom K, Karp K, Lundstrom NG, Segerstedt B, Svensson M, Nordberg G. Pulmonary epithelial integrity in children: Relationship to ambient ozone exposure and swimming pool attendance. Environ Health Perspect 112: 1768-1771, 2004.

28. Miller M, Hankinson J, Brusasco V, Burgos F, Casaburi R, Coates A, Crapo R, Enright P, van der Grinten CP, Gustafsson P, Jensen R, Johnson DC, MacIntyre N, McKay R, Navajas D, Pedersen OF, 
Pellegrino R, Viegi G, Wanger J. Standardisation of spirometry. Eur Respir J 26: 319-338, 2005.

29. Nanson CJ, Burgess JL, Robin M, Bernard AM. Exercise alters serum pneumoprotein concentrations. Respir Physiol 127: 259-265, 2001.

30. Newman S, Moren F, Trofast E, Talaee N, Clarke S. Deposition and clinical efficacy of terbutaline sulphate from turbuhaler, a new multi-dose powder inhaler. Eur Respir J 2: 247-252, 1989.

31. Newman S, Moren F, Trofast E, Talaee N, Clarke S. Terbutlaine sulfate turbuhaler - effect of inhaled flow-rate on drug deposition and efficacy. Int J Pharml 74: 209-213, 1991.

32. Nucci G, Suki B, Lutchen K. Modeling airflow-related shear stress during heterogeneous constriction and mechanical ventilation. $J$ Appl Physiol 95: 348-356, 2003.

33. Omori C, Schofield B, Mitzner W, Freed A. A beta(2)-adrenergic agonist inhibits dry air-induced injury in canine peripheral airways. $J$ Appl Physiol 78: 2169-2179, 1995.

34. Perkins GD, Gao F, Thickett DR. In vivo and in vitro effects of salbutamol on alveolar epithelial repair in acute lung injury. Thorax 63: 215-220, 2008.

35. Persson CGA, Erjefält JS, Andersson M, Greiff L, Svensson C. Extravasation, lamina propria flooding and lumenal entry of bulk plasma exudate in mucosal defence, inflammation and repair. Pulm Pharmacol 9: 129-139, 1996.

36. Quanjer P, Tammeling G, Cotes J, Pedersen O, Peslin R, Yernault J. Lung volumes and forced ventilatory flows. Report working party standardization of lung function tests, European community for steel and coal Official statement of the European Respiratory Society. Eur Respir J 16: 5-35, 1993.

37. Romberg K, Bjermer L, Tufvesson E. Exercise but not mannitol provocation increases urinary clara cell protein $(\mathrm{CC} 16)$ in elite swimmers. Respir Med 105: 31-36, 2011.

38. Singh G, Singh J, Katyal S, Brown W, Kramps J, Paradis I, Dauber JH, Macpherson TA, Squeglia N. Identification, cellular localization, isolation, and characterization of human clara cell-specific $10 \mathrm{KD}$ protein. J Histochem Cytochem 36: 73-80, 1988.

39. Smith PL, Welsh MJ, Stoff JS, Frizzell RA. Chloride secretion by canine tracheal epithelium. I. Role of intracellular c AMP levels. J Membr Biol 70: 217-226, 1982.

40. Wang D, Chen H, Chou C, Hsu K, Freed A. Terbutaline acts at multiple sites to inhibit bronchoconstriction induced by dry air in canine peripheral airways. Am Rev Respir Dis 145: 1295-1300, 1992.

41. Warren JB, Wilson AJ, Loi RK, Coughlan ML. Opposing roles of cyclic AMP in the vascular control of edema formation. FASEB $J$ 7: 1394-1400, 1993.

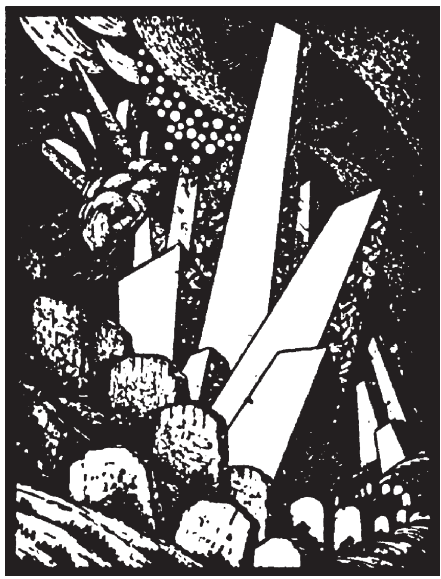

